\title{
ANALISIS KEKUATAN SAMBUNGAN TIANG PANCANG BETON TERHADAP GAYA TARIK, LATERAL, DAN MOMEN PADA TANAH KOHESIF
}

\author{
Kevin Trianto Chiarli ${ }^{1}$, Alfred Jonathan Susilo ${ }^{2}$ \\ ${ }^{1}$ Program Studi Sarjana Teknik Sipil, Universitas Tarumanagara, Jl. Letjen S. Parman No.1 Jakarta \\ Kevin.325170005@stu.untar.ac.id \\ ${ }^{2}$ Program Studi Sarjana Teknik Sipil, Universitas Tarumanagara, Jl. Letjen S. Parman No.1 Jakarta \\ Alfred@ft.untar.ac.id
}

Masuk: 11-01-2021, revisi: 14-01-2021, diterima untuk diterbitkan: 11-03-2021

\begin{abstract}
With the growth of occupation and technological developments, the shape of the building has also changed over time. Changes in the shape of the building bring the need for strength to certain styles and changing moments. Therefore, the foundation as the lower part of the structure as well as the support for the building must be able to withstand the forces that occur. Precast pile foundation is one type of deep foundation that is commonly used today. However, because the foundation is casted outside the field, there is a length limit on the foundation due to transportation, and so on. The foundation connection is a means of unifying precast piles to achieve the desired piling depth. Planning of pile foundation joints is necessary because some types of joints have a reduction in strength that allows failure of the foundation structure. The selection of the right type of connection can result in an efficiency of the needs at a cost. Therefore, the step of determining the type of precast pile connection should be emphasized more to the project development parties.
\end{abstract}

Keywords: joints, precast piles, strength reduction factor

\begin{abstract}
ABSTRAK
Dengan adanya pertumbuhan pendudukan dan perkembangan teknologi, bentuk bangunan dari waktu ke waktu juga mengikuti perubahan yang terjadi. Perubahan bentuk bangunan tersebut membawa kebutuhan kekuatan terhadap gaya dan momen tertentu berubah. Maka dari itu, fondasi sebagai struktur bagian bawah sekaligus penopang bangunan harus mampu menahan gaya-gaya yang terjadi. Fondasi tiang pancang pracetak merupakan salah satu jenis fondasi dalam yang umum digunakan sekarang ini. Namun, dikarenakan fondasi cetak terlebih dahulu di luar lapangan, terdapat batasan panjang pada fondasi tersebut akibat dari segi transportasi, dan sebagainya. Sambungan fondasi merupakan sarana pemersatu tiang pancang pracetak untuk mencapai kedalaman pemancangan yang diinginkan. Perencanaan sambungan fondasi tiang pancang diperlukan karena beberapa jenis sambungan memiliki reduksi kekuatan yang memungkinkan terjadinya kegagalan pada struktur fondasi. Pemilihan jenis sambungan yang tepat dapat menghasilkan suatu efisiensi terhadap kebutuhan dengan biaya yang dikeluarkan. Maka dari itu, langkah penentuan pemilihan jenis sambungan tiang pancang pracetak harus lebih ditekankan kepada para pihak pembangunan proyek.
\end{abstract}

Kata kunci: sambungan, tiang pancang pracetak, faktor reduksi kekuatan

\section{PENDAHULUAN}

Kegagalan pada struktur bangunan merupakan kejadian yang sangat ditakuti baik oleh owner proyek, engineer, dan masyarakat luas. Pertumbuhan penduduk yang semakin meningkat menyebabkan kebutuhan perubahan bentuk bangunan, baik dari segi luas maupun tinggi bangunan. Dengan adanya perubahan bentuk pada bangunan, tentu saja kegagalan struktur tetap harus dihindari demi keamanan dan kenyamanan bersama. Salah satu bentuk kegagalan struktur yang harus dihindari adalah kegagalan pada struktur fondasi.

Struktur fondasi sendiri merupakan struktur bangunan yang paling penting dan mendasar dan memiliki fungsi sebagai sarana penyaluran beban dari struktur atas ke lapisan tanah tertentu. Berdasarkan material bahan yang digunakan, fondasi terbagi menjadi beberapa jenis yang antara lain fondasi kayu, baja, dan beton. Ketiga kelompok fondasi ini memiliki keunggulan dan kekurangan tersendiri, sehingga pemilihan penggunaan bahan tergantung dari 
kebutuhan bangunan yang akan berdiri di atas fondasi tersebut baik dari segi beban bangunan, sifat tanah, kondisi lapangan, dan biaya proyek.

Perubahan gaya hidup dan teknologi yang terjadi juga memberikan perubahan yang cukup signifikan pada bidang teknik sipil. Fungsi dan bentuk bangunan merupakan contoh perubahan yang dapat kita lihat secara langsung saat ini. Perubahan ini dapat menyebabkan kebutuhan tarik dan ketahanan terhadap momen lentur pada fondasi yang mungkin lebih besar daripada fondasi bangunan konvensional.

Fondasi beton seringkali digunakan masyarakat sebagai fondasi untuk bangunan darat yang membutuhkan semen kualitas tinggi dan bangunan tepi laut (Tomlinson \& Woodward, 1977, p. 19). Fondasi beton berdasarkan tempat pembuatannya terbagi menjadi 2 jenis, yaitu Cast-In-Place Concrete Piles (Fondasi Tiang Bor) dan Precast Concrete Piles (Fondasi Tiang Pancang Beton) (Bowles, 1997, pp. 875-880). Pada fondasi tiang pancang beton, terdapat batasan panjang fondasi dikarenakan keterbatasan sistem transportasi dan lain-lain sehingga diperlukan sambungan tiang pancang (Splicing) yang jumlahnya diterapkan hingga memenuhi kedalaman yang dibutuhkan. Selain itu, jenis sambungan juga mempengaruhi kekuatan dari fondasi dalam yang digunakan. Tentu saja setiap sambungan fondasi tiang pancang ini harus memenuhi kebutuhan kekuatan tekan, tarik, dan momen akibat gaya lateral yang timbul berdasarkan gaya luar dan beban struktur atas itu sendiri, agar terhindar dari kegagalan pada sambungan.

Pada penelitian ini, akan ditetapkan rumusan masalah yaitu analisis nilai kebutuhan daya dukung fondasi tiang akibat gaya luar dan jenis sambungan yang mampu menahan kebutuhan gaya tekan, tarik, dan momen dengan menggunakan rumus empiris dan analisis sifat parameter tanah untuk memperoleh gaya aksial (tarik dan tekan) dan momen pada fondasi tiang pancang.

Dalam mendesain fondasi, dibutuhkan berbagai parameter tanah yang dapat diperoleh melalui pengujian lapangan maupun uji laboratorium. Namun, jika data tersebut tidak didapatkan, dapat dilakukan korelasi terhadap data tanah dimana formula korelasi tersebut sudah diteliti oleh para engineer lain. Pada penelitian ini, dilakukan korelasi dari nilai N-SPT yang dapat dilihat pada Gambar 1, Gambar 2, dan Gambar 3 untuk mendapatkan parameter tanah yang dibutuhkan.

\begin{tabular}{lllllll}
\hline SPT $N$ value & $>30$ & $15-30$ & $8-15$ & $4-8$ & $2-4$ & $<2$ \\
\hline Cohesion, $\mathrm{kPa}$ & 192 & $96-192$ & $48-96$ & $24-48$ & $12-24$ & 12 \\
Soil conditions & Hard & Very stiff & Stiff & Firm & Soft & Very soft \\
\hline
\end{tabular}

Gambar 1. Korelasi N-SPT VS C (Karol, 1960)

\begin{tabular}{llllll}
\hline SPT N value & $>50$ & $30-50$ & $10-30$ & $4-10$ & $0-4$ \\
\hline Angle of friction, degree & $>41$ & $36-41$ & $30-36$ & $28-30$ & $<28$ \\
Soil conditions & Very good & Good & Fair & Poor & Very poor \\
\hline
\end{tabular}

Gambar 2. Korelasi N-SPT VS $\Phi$ (Terzaghi \& Peck, 1967) 


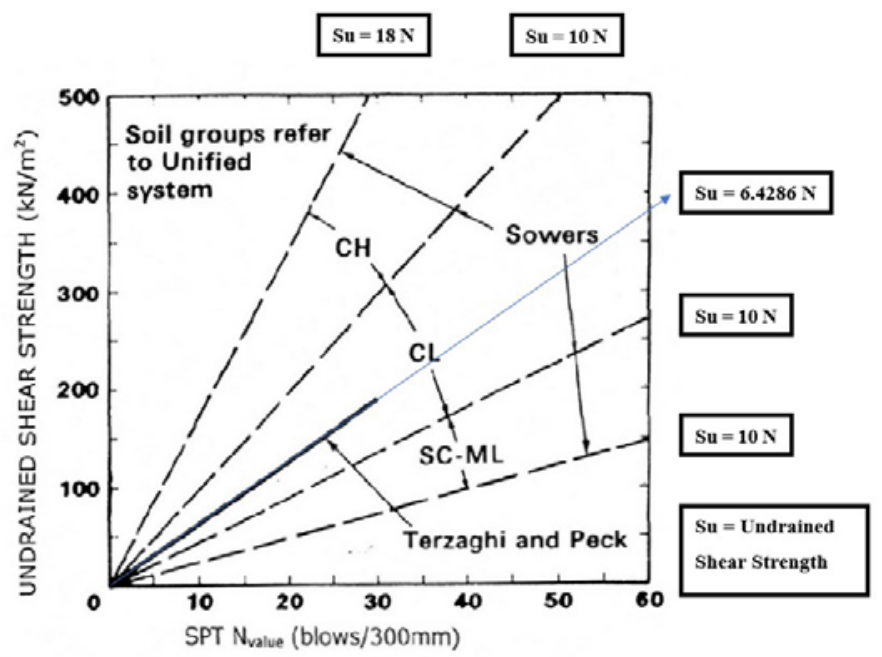

Gambar 3 Korelasi N-SPT VS Su (Terzaghi \& Peck, 1967)

Selain itu, dalam menghitung daya dukung fondasi akan digunakan rumus dan metode sebagai berikut:

1. $\quad$ Metode Meyerhoff (Bowles, 1997) - Daya dukung ujung tiang

2. $\quad$ Metode Alpha (Das, 2007) - Daya dukung selimut tiang

3. $\quad$ Metode Beta (Das, 2007) - Reduksi negative skin friction

4. Metode Broms (Deep Foundation Research Institute Parahyangan Catholic, 2013) - Daya dukung lateral tiang.

Untuk bangunan yang semakin maju dan ukurannya bertambah besar, besar kemungkinan bahwa diperlukan beberapa tiang pancang yang bekerja sama untuk menahan gaya luar. Namun, terdapat nilai yang mungkin menyebabkan reduksi kekuatan dari tiang kelompok tersebut. Reduksi ini kerap disebut sebagai nilai efisiensi tiang kelompok.

Pada penelitian ini, digunakan rumus Chellis dan Vesic (Sayed M., 1992) yang menurut peneliti telah memenuhi karakteristik dari data tanah yang digunakan. Selain itu, jenis sambungan yang dianalisis terdiri dari sambungan dengan faktor reduksi pada daya dukung tarik dan momen seperti Bolognesi-Moretto, Japanese Bolted, Brunsplice, Anderson, Hamilton Form, dan juga sambungan tanpa faktor reduksi seperti Tokyou, Marier, dan Herkules. Bentuk sambungan yang digunakan oleh peneliti dapat dilihat pada Gambar 4, Gambar 5, dan Gambar 6.
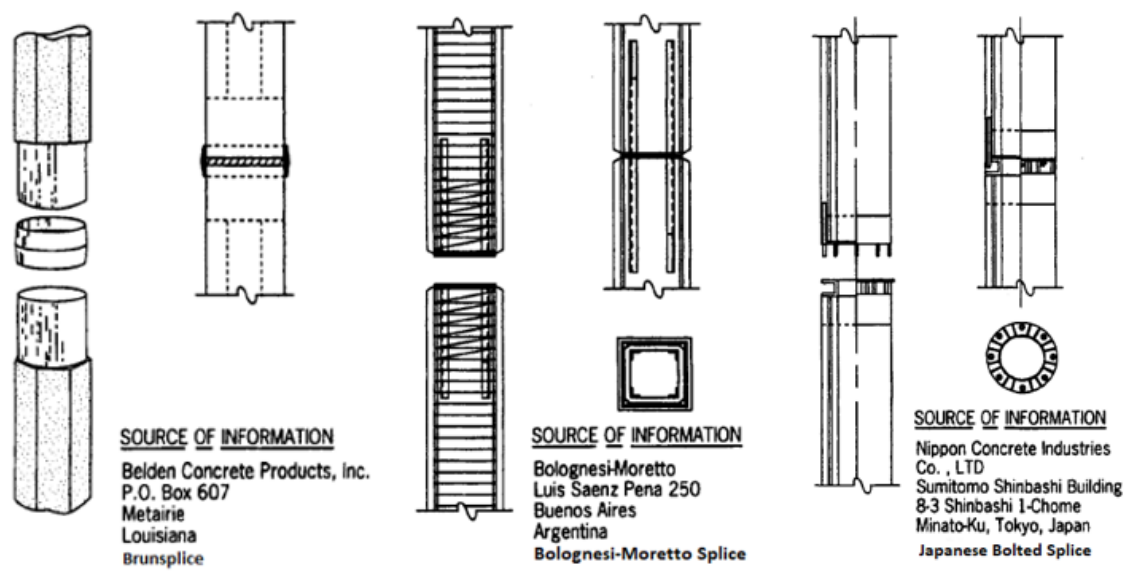

Gambar 4 Sambungan Brunsplice, Bolognesi-Moretto, dan Japanese Bolted (Prakash \& Sharma, 1990) 

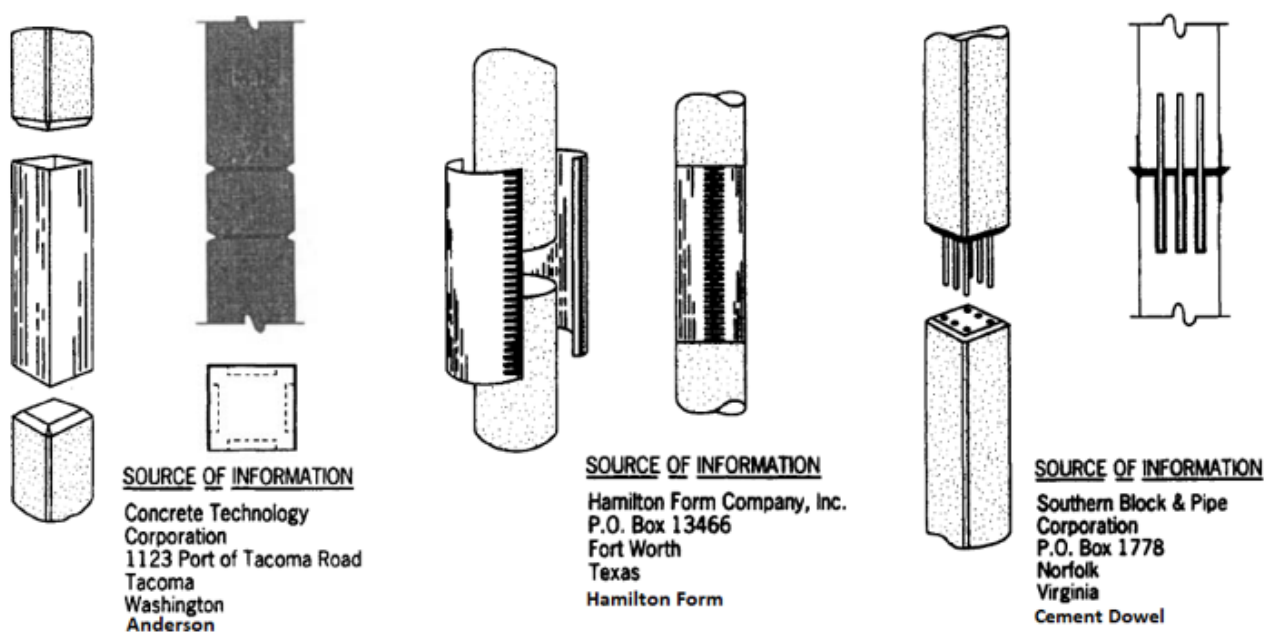

Gambar 5 Sambungan Anderson, Hamilton Form dan Cement Dowel (Prakash \& Sharma, 1990)
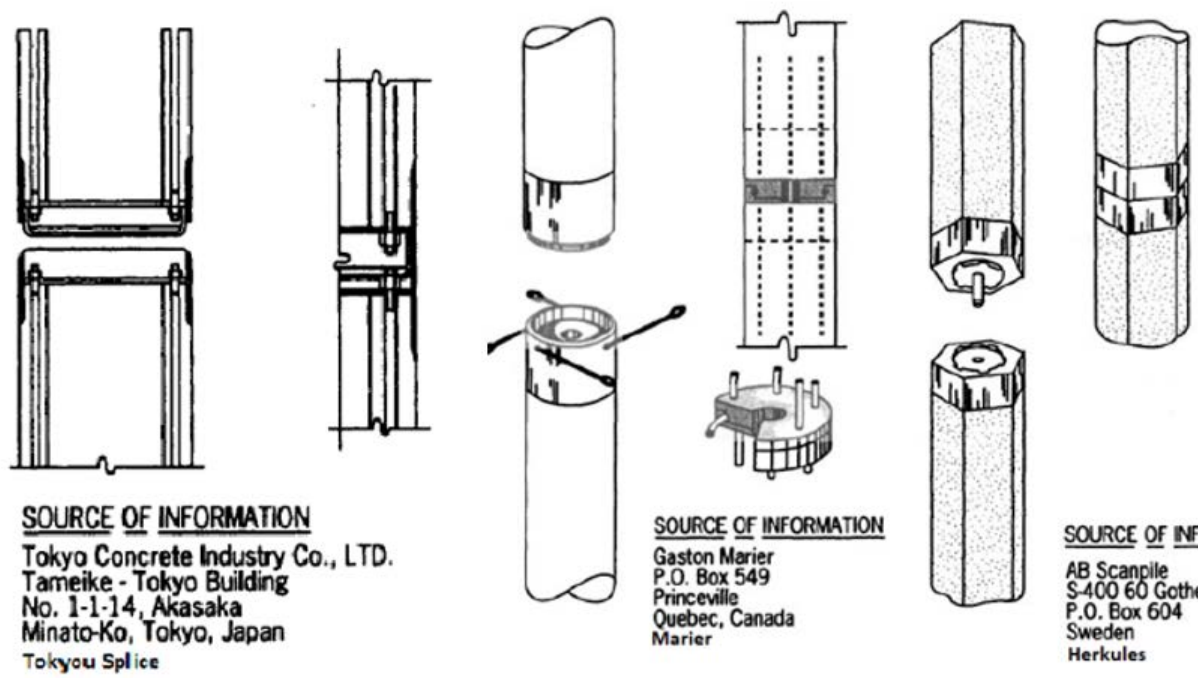

Gambar 6 Sambungan Tokyou, Marier, dan Herkules (Prakash \& Sharma, 1990)

\section{METODE PENELITIAN}

\section{Pengambilan data}

Metode pengambilan data dilakukan dengan uji lapangan. Pengujian yang dilakukan berupa Standard Penetration Test (SPT) yang berlokasi di kota Semarang, Jawa Tengah, Indonesia. Kemudian, digunakan korelasi data tanah untuk mendapatkan nilai parameter tanah seperti kuat geser undrained, kohesi, dan lain-lain. Nilai parameter tanah ini akan menjadi lebih akurat jika dilakukan uji laboratorium pada berbagai titik di lokasi tersebut.

\section{Analisis data}

Desain kebutuhan dan kekuatan dari struktur bawah bangunan tergantung dari kebutuhan kekuatan dari struktur atas. Nilai kebutuhan struktur atas akan lebih akurat jika dilakukan analisis dengan bantuan perangkat lunak analisis struktur. Namun, pada penelitian ini, perhitungan kebutuhan hanya dilakukan dengan kalkulasi kasar. Setelah itu, peneliti akan mendesain fondasi dengan metode trial and error. Sehingga, peneliti mendapatkan hasil yang efisien, baik dari segi biaya maupun daya dukung. Setelah itu, dilakukan analisis terhadap sambungan tiang pancang beton yang akan menjawab tujuan penelitian ini. 


\section{HASIL DAN PEMBAHASAN}

\section{Korelasi data tanah}

Pada penelitian ini, hanya digunakan data bor log yang merupakan hasil dari uji standard penetration test yang diuji pada kota Semarang, Indonesia. Data yang didapatkan berupa nilai N-SPT yang dilakukan sampai dengan 50 meter. Untuk mendapatkan nilai dari parameter tanah lainnya, digunakan berbagai rumus korelasi, hasil dari perhitungan korelasi dapat dilihat pada Tabel 1. Pada pelaksanaan di lapangan, akan lebih akurat jika digunakan data dari uji laboratorium jika dibandingkan dengan data hasil korelasi.

Tabel 1 Data hasil korelasi tanah

\begin{tabular}{|c|c|c|c|c|}
\hline \multicolumn{5}{|c|}{ Korelasi Tanah } \\
\hline $\begin{array}{l}\text { Kedalaman } \\
(\mathrm{m})\end{array}$ & $\begin{array}{c}\text { N-SPT } \\
\text { (pukulan/kaki) }\end{array}$ & $\begin{array}{c}\mathrm{Su} \\
\left(\mathrm{kN} / \mathrm{m}^{2}\right)\end{array}$ & $\begin{array}{c}\mathrm{Cu} \\
\left(\mathrm{kN} / \mathrm{m}^{2}\right)\end{array}$ & $\begin{array}{l}\Phi \\
(\circ)\end{array}$ \\
\hline 0 & 0 & 0 & 0 & 0 \\
\hline 2 & 0 & 0 & 0 & 0 \\
\hline 4 & 0 & 0 & 0 & 0 \\
\hline 6 & 0 & 0 & 0 & 0 \\
\hline 8 & 0 & 0 & 0 & 0 \\
\hline 10 & 0 & 0 & 0 & 0 \\
\hline 12 & 0 & 0 & 0 & 0 \\
\hline 14 & 0 & 0 & 0 & 0 \\
\hline 16 & 0 & 0 & 0 & 0 \\
\hline 18 & 0 & 0 & 0 & 0 \\
\hline 20 & 0 & 0 & 0 & 0 \\
\hline 22 & 0 & 0 & 0 & 0 \\
\hline 24 & 0 & 0 & 0 & 0 \\
\hline 26 & 0 & 0 & 0 & 0 \\
\hline 28 & 0 & 0 & 0 & 0 \\
\hline 30 & 0 & 0 & 0 & 0 \\
\hline 32 & 15 & 96,429 & 96 & 31,5 \\
\hline 34 & 8 & 51,428 & 48 & 29,332 \\
\hline 36 & 11 & 70,715 & 68,571 & 30,3 \\
\hline 38 & 8 & 51,429 & 48 & 29,332 \\
\hline 40 & 10 & 64,286 & 61,714 & 30 \\
\hline 42 & 14 & 90 & 89,142 & 31,2 \\
\hline 44 & 12 & 77,143 & 75,428 & 30,6 \\
\hline 46 & 16 & 102,857 & 102,4 & 31,8 \\
\hline 48 & 20 & 128,572 & 128 & 33 \\
\hline 50 & 25 & 160,715 & 160 & 34,5 \\
\hline
\end{tabular}

\section{Gaya luar dari struktur atas}

Pada umumnya, nilai dari gaya luar yang terjadi pada fondasi didapatkan dengan menggunakan kalkulasi struktur atas dengan software analisis struktur yang memungkinkan perhitungan dengan berbagai kombinasi pembebanan. Pada penelitian ini, nilai dari gaya luar didapatkan dari perhitungan secara kasar untuk gaya aksial, nilai base shear dengan magnitude kota Semarang untuk gaya lateral. Untuk nilai maksimum momen lentur fondasi, peneliti menggunakan bantuan software sehingga didapatkan kurvatur momen lentur terhadap kedalaman tanah. Rangkuman dari perhitungan gaya luar yang digunakan pada penelitian ini dapat dilihat pada Tabel 2. Nilai momen maksimum didapatkan dari grafik tersebut (Gambar 7) pada kedalaman \pm 7,5 $\mathrm{m}$ di bawah permukaan tanah.

\section{Desain Fondasi}

Rumus empiris digunakan untuk menentukan kekuatan dari tiang pancang pada tanah kohesif. Untuk gaya aksial tekan fondasi, digunakan rumus metode Meyerhoff untuk daya dukung ujung tiang, dan metode Alpha untuk daya dukung selimut tiang. Sedangkan, untuk gaya aksial tarik, digunakan metode Beta untuk menghitung nilai gesekan kulit negative yang mereduksi daya dukung tarik tiang pancang. Kemudian, untuk gaya lateral, digunakan metode 
Broms karena semua lapisan tanah tergolong kohesif jika dilihat berdasarkan bor-log. Dan yang terakhir, kekuatan momen lentur ditentukan dari brosur tiang pancang.

Pada penelitian ini, dilakukan trial and error saat mendesain fondasi, dimana hasilnya akhirnya dapat dilihat pada Tabel 2. Peneliti menggunakan formasi tiang pancang dari (Wika, 2020) dengan diameter 800 mm sebanyak 9 tiang dalam 1 buah pile cap yang ditanam sedalam $50 \mathrm{~m}$.

Tabel 2 Gaya luar \& rangkuman trial and error

\begin{tabular}{cccc}
\hline Notasi & Deskripsi & Satuan & Nilai \\
\hline Pult & Daya Dukung Tekan & Ton & 3287,81 \\
Tult & Daya Dukung Tarik & Ton & 470,74 \\
Qult & Daya Dukung Lateral & Ton & 329,20 \\
Mult & Daya Dukung Momen Lentur & Tonm & 130 \\
P & Gaya Tekan Luar & Ton & 1573,11 \\
T & Gaya Tarik Luar & Ton & 427,59 \\
Q & Gaya Lateral Luar & Ton & 144,73 \\
M & Momen Lentur Luar & Tonm & 96,57 \\
\hline
\end{tabular}

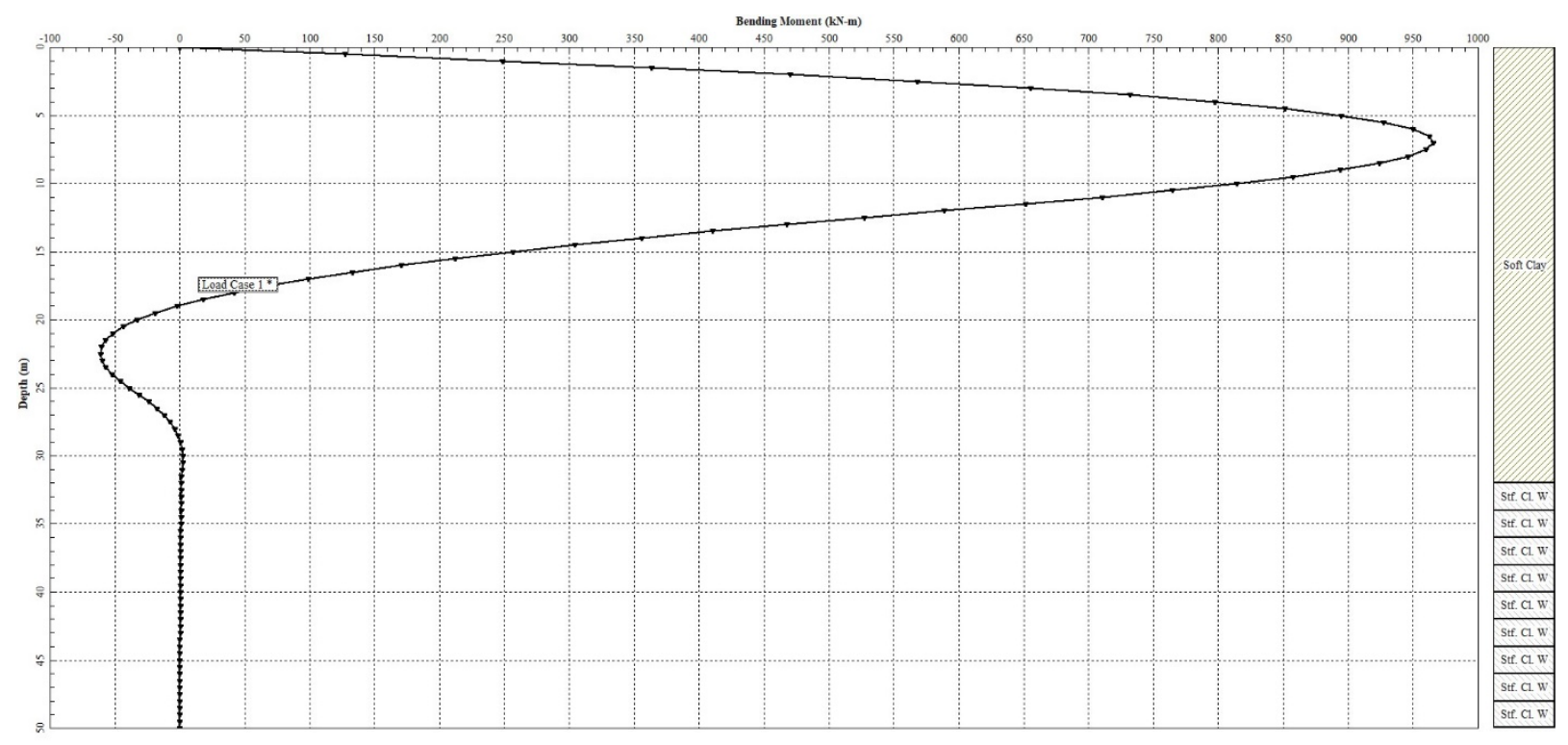

Gambar 7 Grafik momen VS kedalaman tanah

\section{Sambungan Tiang Pancang}

Dalam menentukan sambungan pada tiang pancang, kekuatan sambungan didapatkan dari kekuatan fondasi sendiri yang direduksi dengan persentase reduksi dari masing-masing jenis sambungan. Pada penelitian ini, peneliti menganalisis sambungan yang memiliki faktor reduksi seperti sambungan Bolognesi - morretto, Japanese bolted, Brunsplice, Anderson, Hamilton form, Cement dowel, Mouton, dan juga sambungan tanpa faktor reduksi seperti Tokyou, Marier, dan Herkules. Persentase faktor reduksi dan daya dukung ultimit sambungan dapat dilihat pada Tabel 3. Sedangkan, untuk kondisi sambungan yang dianalisis dapat dilihat pada Tabel 4. 
Tabel 3 Gaya luar \& rangkuman trial and error

\begin{tabular}{ccccccccc}
\hline Tipe sambungan & \multicolumn{3}{c}{ Faktor reduksi sambungan } & \multicolumn{3}{c}{ Daya dukung sambungan } \\
\cline { 2 - 9 } & $\begin{array}{c}\text { Kekuatan } \\
\text { tekan }\end{array}$ & $\begin{array}{c}\text { Kekuatan } \\
\text { tarik }\end{array}$ & $\begin{array}{c}\text { Kekuatan } \\
\text { lateral }\end{array}$ & $\begin{array}{c}\text { Momen } \\
\text { lentur }\end{array}$ & Pult & Tult & Qult & Mult \\
\hline Satuan & $(\%)$ & $(\%)$ & $(\%)$ & $(\%)$ & (ton) & (ton) & (ton) & (tonm) \\
\hline Bolognesi - moretto & 100 & 55 & 100 & 100 & 3287,81 & 258,91 & 329,201 & 130 \\
Japanese bolted & 100 & 90 & 90 & 90 & 3287,81 & 423,67 & 296,281 & 117 \\
Brunsplice & 100 & 20 & 50 & 50 & 3287,81 & 94,149 & 164,600 & 65 \\
Anderson & 100 & 0 & 100 & 100 & 3287,81 & 0 & 329,201 & 130 \\
Hamilton form & 100 & 75 & 100 & 100 & 3287,81 & 353,059 & 329,201 & 130 \\
Cement dowel & 100 & 40 & 65 & 65 & 3287,81 & 188,298 & 213,980 & 84.5 \\
Mouton & 100 & 40 & 100 & 100 & 3287,81 & 188,298 & 329,201 & 130 \\
Tokyou & 100 & 100 & 100 & 100 & 3287,81 & 470,745 & 329,201 & 130 \\
Marier & 100 & 100 & 100 & 100 & 3287,81 & 470,745 & 329,201 & 130 \\
Herkules & 100 & 100 & 100 & 100 & 3287,81 & 470,745 & 329,201 & 130 \\
\hline
\end{tabular}

Tabel 4 Kondisi sambungan

\begin{tabular}{ccccc}
\hline Tipe sambungan & \multicolumn{4}{c}{ Kondisi sambungan } \\
\cline { 2 - 5 } & Tekan & Tarik & Lateral & $\begin{array}{c}\text { Momen } \\
\text { lentur }\end{array}$ \\
\hline Satuan & - & - & - & - \\
\hline Bolognesi - moretto & Aman & Gagal & Aman & Aman \\
Japanese bolted & Aman & Gagal & Aman & Aman \\
Brunsplice & Aman & Gagal & Aman & Gagal \\
Anderson & Aman & Gagal & Aman & Aman \\
Hamilton form & Aman & Gagal & Aman & Aman \\
Cement dowel & Aman & Gagal & Aman & Gagal \\
Mouton & Aman & Gagal & Aman & Aman \\
Tokyou & Aman & Aman & Aman & Aman \\
Marier & Aman & Aman & Aman & Aman \\
Herkules & Aman & Aman & Aman & Aman \\
\hline
\end{tabular}

\section{KESIMPULAN DAN SARAN}

\section{Kesimpulan}

Berdasarkan hasil dari analisis yang telah dilakukan, penulis menemukan beberapa kesimpulan sebagai berikut:

1. Dengan gaya luar yang terjadi berdasarkan data dan asumsi dari penulis, semua sambungan yang telah dianalisis tidak mampu menahan gaya tarik.

2. Jika sambungan diletakkan pada titik momen lentur maksimum yaitu di kedalaman 7,5 m, sambungan Brunsplice dan Cement Dowel akan mengalami kegagalan terhadap momen lentur pada sambungan.

3. Semua jenis sambungan tidak memiliki reduksi nilai kekuatan terhadap daya dukung aksial tekan.

4. Jika terdapat gaya tarik pada salah satu kombinasi pembebanan yang dilakukan saat menganalisis struktur atas, sambungan Anderson dan Brunsplice kurang baik untuk digunakan pada fondasi tiang pancang.

5. Titik penentuan letak sambungan tiang pancang dipengaruhi oleh kurvatur momen lentur fondasi.

\section{Saran}

Saran dari analisis yang penulis lakukan adalah sebagai berikut:

1. Saat mendesain fondasi tiang pancang yang memiliki sambungan, sebaiknya dilakukan pengecekan terhadap sambungan tiang pancang. Pengecekan dapat meliputi kekuatan aksial tarik, lateral, maupun momen agar struktur bangunan tidak gagal akibat sambungan.

2. Kondisi tanah pada semua lapisan harus diperhitungkan karena dapat menimbulkan gaya yang memungkinkan kegagalan pada sambungan tiang pancang. 
3. Peletakan sambungan tiang pancang disarankan berada pada posisi yang memiliki risiko kegagalan paling minim. Hal ini dapat dilihat dari kurvatur momen lentur fondasi dan bertujuan untuk menghindari kegagalan pada sambungan tiang pancang akibat momen lentur.

\section{DAFTAR PUSTAKA}

Bowles, Joseph E. Foundation Analysis And Design. Singapore: The McGraw-Hill Companies, Inc., 1997.

Das, Braja M. Principles of Foundation Engineering. Global Engineering, 2007.

Deep Foundation Research Institute Parahyangan Catholic. Manual Pondasi Tiang. Universitas Katolik Parahyangan, 2013.

Karol. Soils and Soil Engineering. Prentice Hall, 1960.

Prakash, Shamsher and Hari D. Sharma. Pile Foundations In Engineering Practice. A Wiley-Interscience Publication, 1990.

Sayed M., Reda M. Bakeer. “Efficiency Formula For Pile Groups.” ASCE Library (1992).

Terzaghi, Karl Von and Ralph Brazelton Peck. Soil Mechanics in Engineering Practice. New York, 1967.

Tomlinson, Michael and John Woodward. Pile Design And Construction Practice. CRC Press, 1977.

Wika. "Wika Beton.” 6 September 2020. Brosur Wika Beton. <https://www.wika-beton.co.id/downloadbrosur/eng>. 